\title{
Findings concerning testis, vas deference, and epididymis in adult cases with nonpalpable testes
}

\author{
Coskun Sahin, Mehmet Kalkan, Soner Yalcinkaya \\ Department of Urology (CS, MK), Sema Hospital, Istanbul and Department of Urology (SY), \\ Antalya Education and Research Hospital, Antalya - Turkey
}

\begin{abstract}
In this study, we aimed to state the relationship between testis, epididymis and vas deference, in adult cases with nonpalpable testis.

Between January 1996 and December 2009, we evaluated 154 adult cases with nonpalpable testes. Mean age was 23 years (20-27 years). Explorations were performed by open inguinal incision, laparoscopy, and by inguinal incision and laparoscopy together on 22, 131 and 1 patient, respectively.

Of all the unilateral cases, 32 were accepted as vanishing testis. In five of these cases, vas deference was ending inside the abdomen, and in the others, it was ending inside the scrotum. In the remaining 99 unilateral and 22 bilateral cases, 143 testes were found in total.

Testes were found in the inguinal canal as atrophic in one case, at the right renal pedicle level with dysmorphic testis in one case, and anterior to the internal ring between the bladder and the common iliac vessels at a smaller than normal size in 119 cases. One $(0.69 \%)$ case did not have epididymis. While epididymis was attached to the testis only at the head and tail locations in $88(61.53 \%)$ cases, it was totally attached to the testis in $54(37.76 \%)$ cases.

There is an obviously high incidence rate of testis and vas deference anomalies, where epididymis is the most frequent one. In cases with abdominal testes, this rate is highest for high localised abdominal testes.
\end{abstract}

Key words: testis; surgery; abnormalities; Vas Deferens

Int Braz J Urol. 2011; 37: 727-732

\section{INTRODUCTION}

Testes are the predominant endocrine organs, which have been localised posterior to the abdominal cavity in the early fetal period. Although they are in the abdomen in most $(90.54 \%)$ of the cases until the $23^{\text {rd }}$ week, they begin to migrate down to the scrotum around $28^{\text {th }}$ week (1). During this migration, testes can occasionally be localised at the higher or lower abdomen, inner opening of the inguinal canal and between the opening of the external inguinal canal and the scrotum (2). It is hypothesized that the epididymis has a major role in the localisation of the testis in the scrotum. In fact, the situation which states that, epididymal anomalies are present in more than $50 \%$ of the higher abdominal testes, supports this theory $(3,4)$.

In this study, we report our results of testis, epididymis and vas deference abnormalities in patients with nonpalpable testes by open surgical exploration and laparoscopic interventions.

\section{MATERIALS AND METHODS}

Explorations were performed by open inguinal and laparoscopic intervention.

During laparoscopic interventions, 3 port accesses (sub-umbilical 1 port, and pararectal 2 ports) were used. In 9 of bilateral nonpalpable testis cases, for who single session laparoscopic orchiopexy 
was performed; a $4^{\text {th }}$ port was placed trans-scrotally, whereas in 13 of these cases, double session orchiopexy was performed. Of the 32 cases with vanishing testis, vas deference excision was performed by inguinal exploration in 5 cases, and by laparoscopic intervention in the remaining 27 cases. Testis dimensions were calculated according to the graphical method. This method includes graphics of testis figures and predefined testicular volumes on paper (Figure-1). Abdominal testicular dimensions were compared with normal scrotal testicular values.

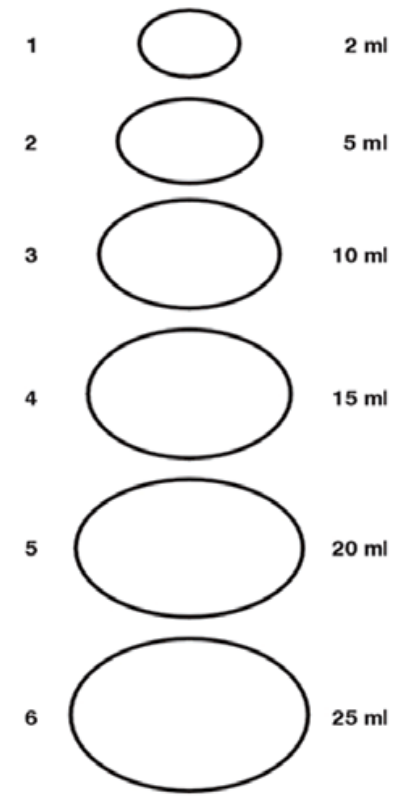

Figure 1 - Scheme for graphic measurement of testicular volume.

Table 1 - Findings concerning the vas deference.
Epididymal configurations were evaluated with a 1 to 5 classification system which defines the relation between epididymis and testis. Normal epididymis is completely attached to the testis at the upper pole of it. However, it is attached to the testis by a fibrous film at the lower pole. Such a configuration is known as type I, and the configuration where the epididymis is completely attached to the testis is known as type II. In type III and IV, head and tail portions are attached respectively to the testis and in type $\mathrm{V}$ the epididymis is completely unattached to the testis.

Laparoscopic orchiectomy was performed on unilateral nonpalpable testis cases. Excised testicular tissues and nubbins were evaluated pathologically.

\section{RESULTS}

No testis could be found in 32 patients during explorations or laparoscopy, and these patients were accepted as having vanishing testes. Vas deference was ending inside the abdomen in 5 cases and in the scrotum in 27 cases (Table-1). In one patient however, while the testis was located inside the abdomen, vas deference on the same side, was ending at the scrotum independent of the testis. Viable testis tissue was diagnosed pathologically, in only 4 $(12.5 \%)$ of the 32 patients, who had vas deference excision. In one patient, right testis was found at the renal pedicle level with an dimorphic structure (Figure-2). In another patient however, during inguinal exploration, the testis was found as atrophic in size $(1 \mathrm{~cm})$. Both testes were at lower intra-abdominal re-

\section{Finding}

\section{no}

Absence of vas deference

1

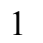

2

20

113

Total

137 
Figure 2 - Right testes is localised in the right renal pedicle and no epididymis (type V epididymal configuration).

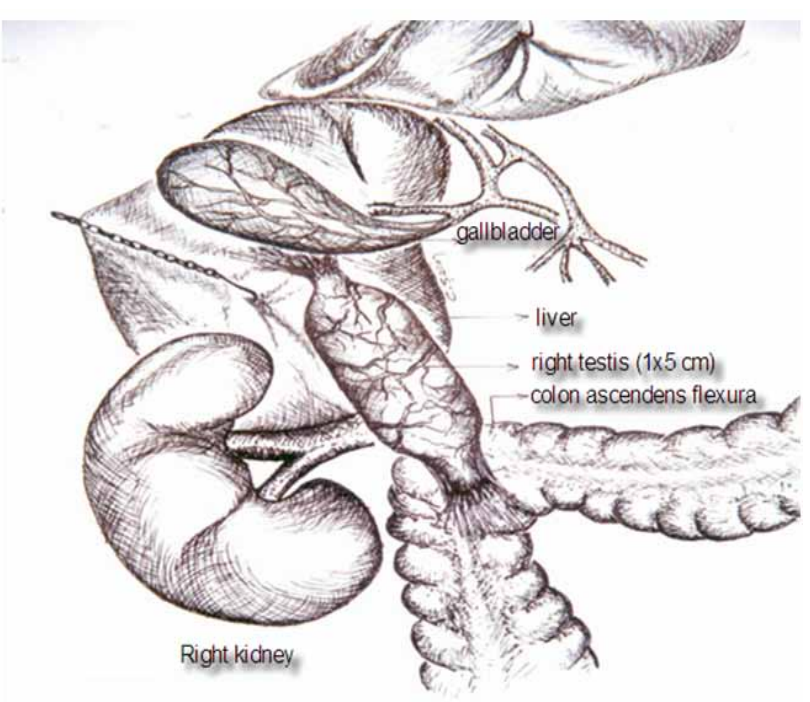

gion in 22 patients with bilateral nonpalpable testes. In 99 of the 131 cases with unilateral nonpalpable testis, testes were found at either anterior to the internal ring, or over the common iliac vessels, or between the bladder and the common iliac vessels.

In all of the cases with intra-abdominal testis, testis volumes were determined as 12.5-22.5 $\mathrm{cm}^{3}$ (average $17.5 \mathrm{~cm}^{3}$ ). Mean testicular volume was $22.5 \mathrm{~cm}^{3}$ in the control group. While the testes were tense (Tight) in 3 cases, they were less dense than the normal density value in the remaining cases (Table-2). One case did not have epididymis (Type V epididymal configuration, Figure-2). While the epididymis was attached to the testis only at the head and tail locations (Type I epididymal configuration, Figure-3) in 88 of the remaining 143 testes, it was totally attached to the testis (Type II epididymal configuration, Figure-4) in the other 54 testes (Table-3).

Carcinoma in-situ was not determined in any of the orchiectomy applied cases. No spermatogenetic activity was detected in testis specimens. Sertoli cells were present in only 4 testicular tissues (Sertoli cell only syndrome). All other testicles had leydig cells.

\section{DISCUSSION}

Cryptorchidism is a congenital anomaly seen in $3 \%$ of term born children. Cases with nonpalpable testes comprise $20-34 \%$ of such anomalies $(5,6)$. It is known that, the frequency of testis-epididymis anomalies is higher in high localised testes (7). In the literature, the frequency of epididymal anomalies is reported to be between $36 \%$ and $75 \%$ and such anomalies are divided into 5 groups (8). However, some investigators claim that there is not a correlation between the testis localisation, and epididymal anomaly (3). It had also been reported that, the frequency of epididymal anomalies among healthy children with undescended testis was $40 \%$ (8). Normal epididymis is completely attached to the testis at the upper pole. However, it is attached to the testis by a fibrous film at the lower pole. In this study of fetal testes, Favorito had determined that as high as $89 \%$ of the cases were in type I, $7.53 \%$ were in type II, $2.05 \%$ were in type III, and $0.68 \%$ were in type IV configuration. He did not detect any type $\mathrm{V}$ configuration (3). In their studies about chil-

Table 2 - Testis anomalies.

\begin{tabular}{|c|c|c|c|c|c|}
\hline & $\begin{array}{l}\text { Normal size } \\
\text { (n) }\end{array}$ & $\begin{array}{c}\text { Small size } \\
\text { (n) }\end{array}$ & $\begin{array}{c}\text { Dysmorphic testis } \\
\text { (n) }\end{array}$ & $\begin{array}{c}\text { Atrophic size } \\
\text { (n) }\end{array}$ & $\begin{array}{c}\text { Total } \\
\text { (n) }\end{array}$ \\
\hline High abdominal testis & - & - & 1 & - & 1 \\
\hline Low abdominal testis & 17 & 94 & - & - & 111 \\
\hline Inguinal testis & - & - & - & 1 & 1 \\
\hline Total (n) & 17 & 94 & 1 & 1 & 113 \\
\hline
\end{tabular}


Figure 3 - Head and tail portions of epididymis attached to the testis (type I configuration).

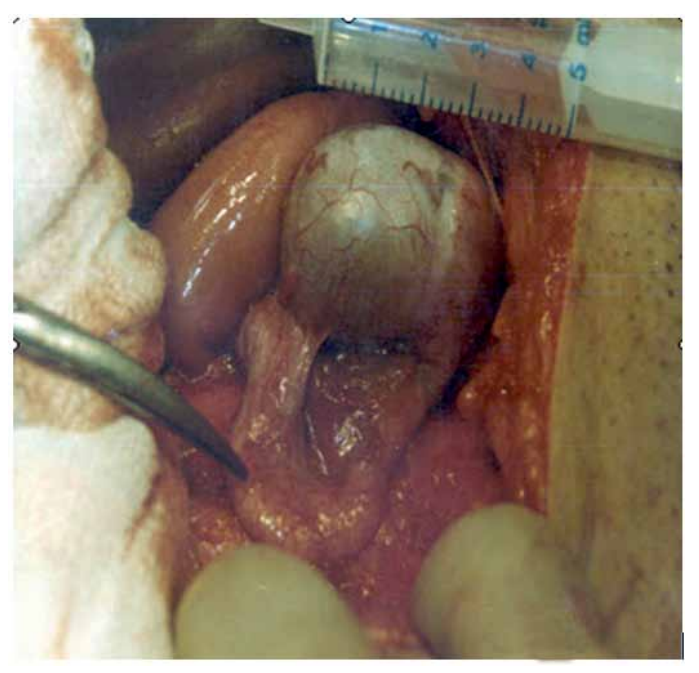

dren aged between 1 month and 18 years, Turek et al. reported that the frequency of type II cases, where the epididymis was completely attached to the testis, was $12 \%$ (9). In our study we determined that 88 $(61.53 \%)$ cases were type I and $54(37.76 \%)$ cases were type II configuration. While type $\mathrm{V}$ configuration was determined in only $1(0.69 \%)$ case, we did not coincide with type III and IV configurations. The case with type V epididymal anomaly had also testicular anomaly located at the higher abdomen. The testis in this case was at the renal pedicle level with the dimensions of $1 \times 1.5 \times 5 \mathrm{~cm}$. When hold by a grasper, it appeared as a tubular organ, and it did not look like a testis. In fact, decisive diagnosis was performed pathologically on this case. It is obvious that, in patients with nonpalpable testes, such high abdominal testes will not be found during inguinal exploration, and will be evaluated as agenetic.

Figure 4 - Epididymis is completely attached to the testis (type II configuration).

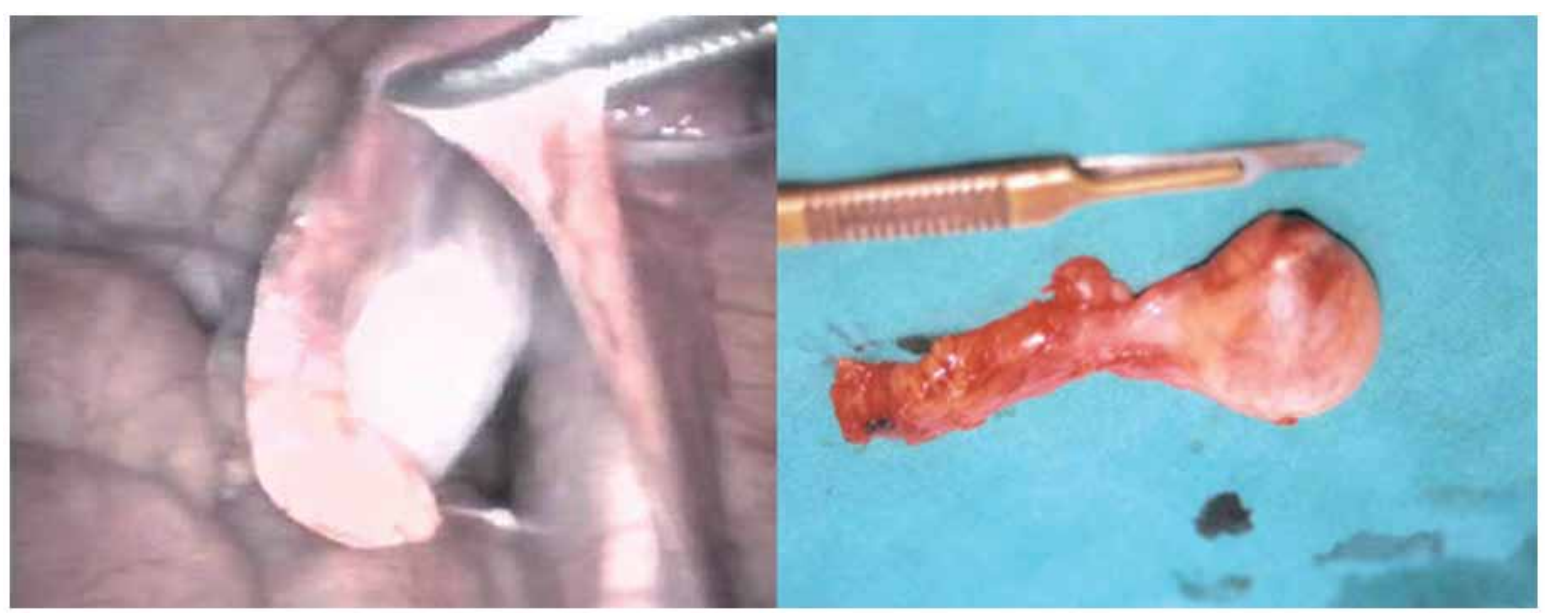

Table 3 - Epididymal configurations.

\begin{tabular}{|c|c|c|c|c|c|}
\hline & Type I & Type II & Type III & Type IV & Type V \\
\hline High abdominal testis & - & - & - & - & $1(0.9 \%)$ \\
\hline Low abdominal testis & $72(64 \%)$ & $39(34.2 \%)$ & - & - & - \\
\hline Inguinal testis & - & $1(0.9 \%)$ & - & - & - \\
\hline Total n (\%) & $72(64 \%)$ & $40(35.1 \%)$ & - & - & $1(0.9 \%)$ \\
\hline
\end{tabular}


There are different theories about testicular descent in embryogenic life. Epididymal factor is one of them (8). In our Type $\mathrm{V}$ epididymal configuration subject who didn't contain an epididymis, testis remained in its embryogenic location.

Adult testis dimensions are usually $4 \times 3 \times 2.5$ $\mathrm{cm}$. Testis volume is usually measured by Prader orchidometer or the graphic method (10-12). We used the graphical method to measure the testis volumes (Figure-1). Except the higher abdominal located testis, all testes were in ellipsoidal structure. In one patient, the testis was inside the inguinal canal at an atrophic size $(1 \times 1 \mathrm{~cm})$. Lower abdominal testes are usually located either just proximal to the internal ring, over the common iliac vessels, or between the bladder and the common iliac vessels. In these patients, the testis volumes were measured between 12.5 and $22.5 \mathrm{~cm}^{3}$ (average $17.5 \mathrm{~cm}^{3}$ ). Average testis volume in the control group of 20 adults who did not have any scrotal pathology was measured as $22.5 \mathrm{~cm}^{3}$. While normal testes were tense and tight when they were palpated, abdominal testes were softer. Higher abdominal testes however, were even softer than the abdominal testes, and the testicular walls were so elastic that they could contact each other upon squeezing. Although the testicular volume of the abdominal testes in our cases seemed to be high at first glance, this situation can be explained by the age group of our cases, which is between 20 and 27 years.

Testes that are not detected by laparoscopy and inguinal exploration are known as vanishing testes. The etiological reason underlying this phenomenon on is thought to be intrauterine testes torsions (10). We did not detect any testes in 32 of our patients. In 8 cases, which had open exploration, vas deference was observed to be blunted at the scrotum. In one of these patients, testis was found inside the abdomen, and vas deference was ending at the scrotum independent of the testis. As seen in this case, observing blunt ended vas deference during exploration does not mean that testis is absent. Testicular vessels should definitely be seen. In 2 patients however, vas deference was observed to extend higher from the small pelvis and end over the common iliac vessels with the testicular vessels. In patients with vanishing testes, viable tes- ticular tissue ratio was reported to be $0 \%$ to $16 \%$ (13). Some authors are recommending inguinal exploration for laparoscopically undetected testes in cases with nonpalpable testes (14). Only 4 testicular nubbin were contained viable testicular tissues. It is reported that laparoscopic intervention is unnecessary in palpable scrotal testicular nubbins as there was no testis in the abdomen (15).

Inguinal exploration was performed on the first 4 of the vanishing testis cases, whose vas deference and testicular vessels were observed to enter the internal inguinal ring during laparoscopy. While atrophic testis was detected in 1 of these 4 patients, vas deference was ending blunted in the remaining three. After we gained more experience on laparoscopy, vas deference was laparoscopically excised instead of applying inguinal exploration, in these cases. Technically, following the circular incision of peritoneum at the level of internal inguinal ring, testicular vessels and vas deference were excised as being tied with end clip, after they were taken inside the abdomen. In 28 of the 32 patients, who were evaluated as having vanishing testes, no testicular tissue was detected pathologically, whereas in 4 cases viable testicular tissue was found. Viable testicular tissue detection rate is low as seen in these cases. Nearly all of these testicles are located in the scrotal cavity as these testicular nubbins are palpable position in the event of cancer, we don't recommend prophylactic excision.

Abdominal testes were found to be smaller and softer in comparison with the normal ones. We determined that, the incidence of higher abdominal testes was extremely low, but the testis-epididymis anomaly was obvious in such testes. If laparoscopic exploration is not performed in higher abdominal testicles, it may not be always possible to find them during open abdominal surgery. However we think that laparoscopy is not necessary in every nonpalpable case; also it is not needed to perform any intervention including laparoscopy in palpable scrotal nubbin cases.

\section{CONFLICT OF INTEREST}

None declared. 


\section{REFERENCES}

1. Moore KL, Persaud TVN: The Developing Human (Clinically Oriented Embryology). 5th ed. Philadelphia. WB Saunders Company; 1993. pp. 265-301.

2. Sampaio FJ, Favorito LA: Analysis of testicular migration during the fetal period in humans. J Urol. 1998; 159: 540-2.

3. Favorito LA, Sampaio FJ: Anatomical relationships between testis and epididymis during the fetal period in humans (10-36 weeks postconception). Eur Urol. 1998; 33: 121-3.

4. Kirsch AJ, Escala J, Duckett JW, Smith GH, Zderic SA, Canning DA, et al.: Surgical management of the nonpalpable testis: the Children's Hospital of Philadelphia experience. J Urol. 1998; 159: 1340-3.

5. Husmann DA, Levy JB: Current concepts in the pathophysiology of testicular undescent. Urology. 1995; 46: 267-76.

6. Sampaio FJ, Favorito LA, Freitas MA, Damião R, Gouveia E: Arterial supply of the human fetal testis during its migration. J Urol. 1999; 161: 1603-5.

7. Kiely EA: Scientific basis of testicular descent and management implications for cryptorchidism. $\mathrm{Br} \mathrm{J}$ Clin Pract. 1994; 48: 37-41.

8. Marshall FF, Shermeta DW: Epididymal abnormalities associated with undescended testis. J Urol. 1979; 121: 341-3.
9. Turek PJ, Ewalt DH, Snyder HM 3rd, Duckett JW: Normal epididymal anatomy in boys. J Urol. 1994; 151: 726-7.

10. Tanagho EA, McAninch JW: Smith's General Urology. 15th (ed.), New York. McGraw-Hill Company. 2000.

11. Takihara H, Sakatoku J, Fujii M, Nasu T, Cosentino MJ, Cockett AT: Significance of testicular size measurement in andrology. I. A new orchiometer and its clinical application. Fertil Steril. 1983; 39: 836-40.

12. Chipkevitch E, Nishimura RT, Tu DG, Galea-Rojas M: Clinical measurement of testicular volume in adolescents: comparison of the reliability of 5 methods. J Urol. 1996; 156: 2050-3.

13. Nishizawa S, Suzuki K, Tachikawa N, Nukui A, Kumamaru T, Shioji $Y$, et al.: The vanishing testis: diagnosis and histological findings. Nihon Hinyokika Gakkai Zasshi. 2000; 91: 537-41.

14. Merry C, Sweeney B, Puri P: The vanishing testis: anatomical and histological findings. Eur Urol. 1997; 31: 65-7.

15. Sahin C, Yigit T, Ozbey I: Adult nonpalpable testis: is laparoscopy always required? J Laparoendosc Adv Surg Tech A. 2002; 12: 431-4.

\section{Correspondence address:}

Dr. Soner Yalcinkaya

Antalya Education and Research Hospital

Varlık Mah. Kazım Karabekir Cad.

Soğuksu, 07070, Antalya, Turkey

Fax: + 902422494462

E-mail: drs1092@gmail.com

Submitted for publication:

January 24, 2011 